\title{
Sodium Gill Potential as a Tool to Monitor Valve Closure Behavior in Freshwater Clam Corbicula fluminea in Response to Copper
}

\author{
Chung-Min Liao ${ }^{1}{ }^{*}$, Chieh-Ming Lin ${ }^{1}$, Li-John Jou ${ }^{2}$, and Wei-Yu Chen ${ }^{1}$ \\ ${ }^{1}$ Department of Bioenvironmental Systems Engineering, National Taiwan University, Taipei, Taiwan \\ 10617, R.O. China; E-Mails: cmliao@ntu.edu.tw; r94622016@ntu.edu.tw; f96622016@ntu.edu.tw \\ ${ }^{2}$ Department of Biomechatronic Engineering, National Ilan University, Ilan, Taiwan 260, R.O. China; \\ E-mail: 1jjou@niu.edu.tw
}

* Author to whom correspondence should be addressed; E-mail: cmliao@ntu.edu.tw

Received: 2 July 2008; in revised form: 14 August 2008 / Accepted: 28 August 2008 /

Published: 1 September 2008

\begin{abstract}
Valve closure behavior in freshwater clam Corbicula fluminea is a biologically sensitive endpoint. The purpose of this paper was to derive an electrophysiological response model of $C$. fluminea to assess copper $(\mathrm{Cu})$-sodium $(\mathrm{Na})$ interactions in gill membrane, whereby valve closure behavior and $\mathrm{Cu}$ toxicity could be monitored. The proposed model was based on the integration of $\mathrm{Cu}$ bioavailability, $\mathrm{Na}$ and $\mathrm{Cu}$ internalizations, and electrochemically-based gill potentials. Based on $\mathrm{Na}$ active transport under non-equilibrium conditions, predicted gill potential of $-8.2 \mathrm{mV}$ agreed reasonably well with published the measured transepithelial potential of $-7 \mathrm{mV}$ in $C$. fluminea. Our proposed framework captured the general features observed in model applications including: (i) 50\% inhibitory $\mathrm{Cu}^{2+}$ activities for $\mathrm{Na}$ membrane potential $\left(E_{\mathrm{Na}}\right)$ and uptake rate $\left(J_{\mathrm{Na}}\right)$ were estimated to be 0.072 and $0.043 \mu \mathrm{M}$, respectively, with a stoichiometry of $3 \mathrm{Cu}^{2+}: 1 E_{\mathrm{Na}}$ and $1 J_{\mathrm{Na}}$; (ii) the external $\mathrm{Cu}^{2+}$-dependent internal $\mathrm{Na}$ concentration could be parsimoniously estimated, and (iii) the site-specific clam gill potentials could be monitored. Here we provided a new approach to monitor waterborne metal toxicity to reduce the nationwide economic losses due to bans on harvesting of contaminated clam and the potential risks to the health of clams.
\end{abstract}


Keywords: Clam; Corbicula fluminea; Bioavailability; Gill membrane potential; Electrophysiology; Valve closure behavior

\section{Introduction}

Freshwater clam Corbicula fluminea is a commercially important native bivalve species and has a high market value to Taiwan's aquaculture (http://www.fa.gov.tw), with wide farming distribution in the western and eastern coastal areas of Taiwan. We recognized that bivalves were a popular choice of sentinel organisms for biological early warning system (BEWS) to monitor the impact of pollutants in aquatic ecosystems [1-10]. Moreover, the dynamic metal speciation analysis in aquatic ecosystems is emerging as a powerful tool basis for prediction developments of bioavailability and reliable risk assessment strategies [11-13]. Here we proposed a framework inspired from key concepts of ecotoxicology (i.e., $\mathrm{Cu}$ bioavailability), biology (i.e., $\mathrm{Na}^{+}$transport kinetics and $\mathrm{Na}^{+} / \mathrm{K}^{+}-\mathrm{ATPase}$ activity) and electrochemistry (i.e., gill potentials) to present the practical implications of this integrated knowledge based on a rigorous quantitative methodology (Figure 1A).

Morgan and Wood [14] and Zhou et al. [15] indicated that the key mechanism of metal toxicity consists of reduction in $\mathrm{Na}^{+}$uptake by blockade of $\mathrm{Na}^{+} / \mathrm{K}^{+}-\mathrm{ATPase}$ in the gill epithelia of freshwater rainbow trout (Oncorhynchus mykiss). $\mathrm{Na}^{+} / \mathrm{K}^{+}$-ATPase activity has been reported in gills of the oyster (Crassostrea virginica), hard clam (Mercenaria mercenaria), and freshwater mussel (Carunculina texasensis) [16, 17]. Generally, $\mathrm{Na}^{+} / \mathrm{K}^{+}$-ATPase pumps generate concentration gradients of cations across membranes in nearly all cells, providing a polar transmembrane pathway. In each transport cycle, up to a hundred times a second, a single $\mathrm{Na}^{+} / \mathrm{K}^{+}$-ATPase pump exchanges three cytoplasmic $\mathrm{Na}^{+}$ions for two extracellular $\mathrm{K}^{+}$ions and hydrolyses one molecule of ATP, involving an active transport mechanism [18, 19].

Organisms do not have specific transport systems for the vast majority of compounds that are internalized by the cell. Thus, most compounds must borrow existing pathways designed for the essential elements: transport through ion channels, carrier-mediated transport, and active transport, where ions are moved against electrochemical gradients driven by the free energy of ATP hydrolysis. It is known that most trace metals are moved down their electrochemical gradients by simple diffusion (passive transport), diffusion through ion channels or by facilitated diffusion (exchange transport). Once inside the cell, transition metals often play important roles as coenzymes or participate in catalytic processes, due to their ability to adopt several different redox states [20].

In gills of marine teleosts and freshwater bivalves, the $\mathrm{Na}^{+}$transport system is thought to involve transmembrane pores, through which $\mathrm{Na}^{+}$ions move down an electrochemical activity gradient. It indicates that most of the $\mathrm{Na}$ flux-dependent gill potentials occur through the active transport mechanism(s) [21-25]. Many studies have been reported that ion transport processes in freshwater bivalves exhibit saturation kinetics [24, 26-29].

McCorkle and Dietz [24] indicated that $\mathrm{Na}$ transport in $C$. fluminea is efficient and Na balance could be examined by partitioning Na flux into three processes: $(i)$ passive diffusion (efflux $=$ diffusion + 
excretion $=2.87 \pm 0.76 \mu \mathrm{M} \mathrm{Na} \mathrm{g}^{-1} \mathrm{dw} \mathrm{h}^{-1}$ and influx $=0.50 \mu \mathrm{M} \mathrm{Na} \mathrm{g}^{-1} \mathrm{dw} \mathrm{h}^{-1}$ ), (ii) exchange diffusion (influx $=$ efflux $=5.91 \pm 0.80 \mu \mathrm{M} \mathrm{Na} \mathrm{g}^{-1} \mathrm{dw} \mathrm{h}^{-1}$ ), and (iii) active transport (influx $=2.41 \mu \mathrm{M} \mathrm{Na} \mathrm{g}^{-1} \mathrm{dw}$ $\left.\mathrm{h}^{-1}\right)$ (Figure 1B).

Figure 1. (A) Schematic of our proposed framework inspired from key concepts of ecotoxicology, biological physiology, and electrochemistry to derive a clam gill-based membrane interface model for the future design of environmental biomonitoring and prediction of metal toxicity. (B) BLM-based $\mathrm{Cu}$ bioavailability associated with the affinity and capacity of gill to bind copper based on site-specific water quality parameters in that physiological mechanisms of $\mathrm{Na}$ transport in gill-biotic ligand membrane including $(i)$ passive diffusion, (ii) exchange transport, and (iii) active transport.

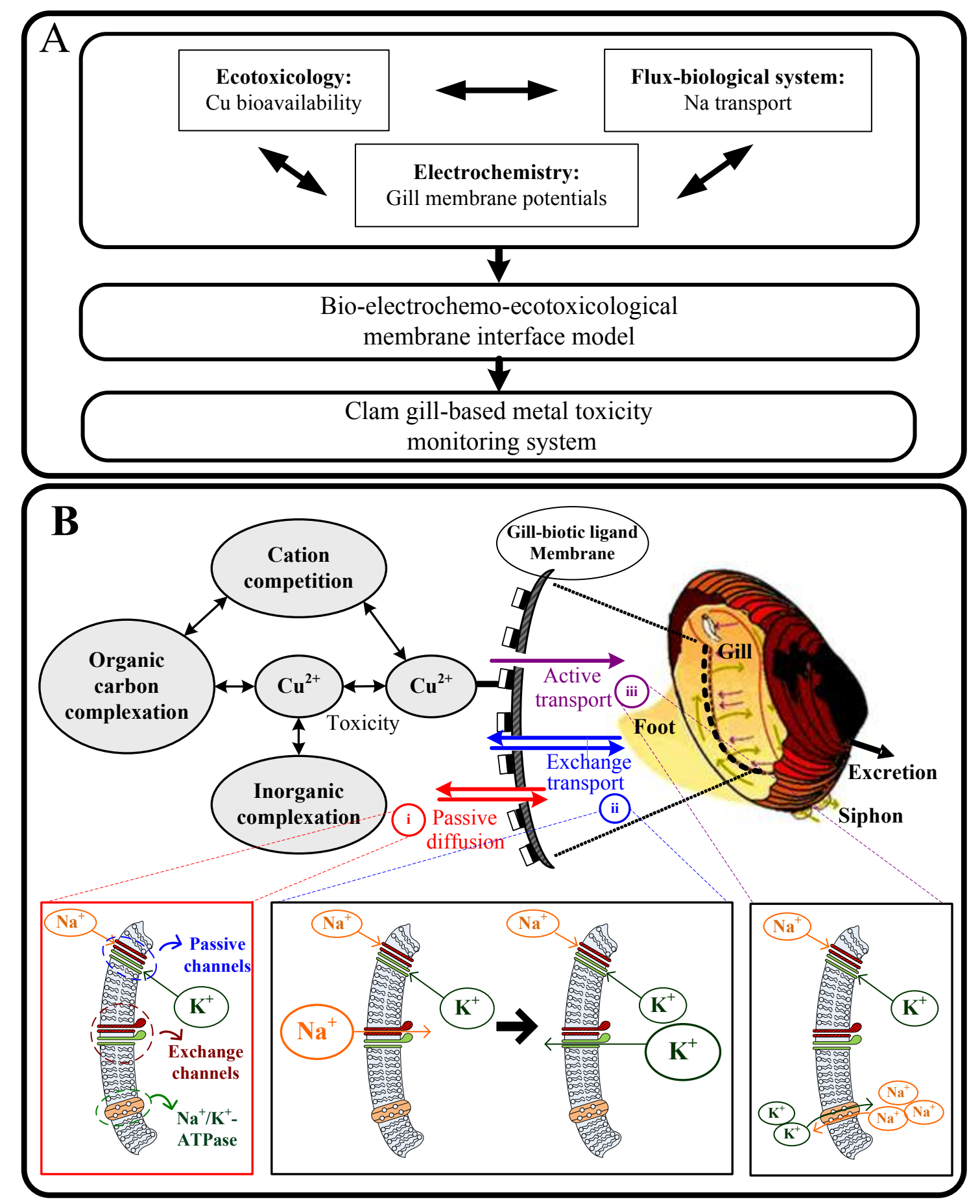


$\mathrm{Na}^{+}$activity-dependent $\mathrm{Na}$ membrane potentials increase from negative to positive with increasing $\mathrm{Cu}$ concentrations, whereas $\mathrm{Cu}^{2+}$ activity-dependent $\mathrm{Na}$ membrane potentials increase from negative to positive with decreasing $\mathrm{Na}^{+}$activities (Figures 2A, B). Figure 2A depicts that gill potentials are depolarized from controlled $-84 \mathrm{mV}$ to $+16 \mathrm{mV}$ in response to waterborne $\mathrm{Cu}$ increasing from 0 to $20 \mu \mathrm{g}$ $\mathrm{L}^{-1}$. Figure $2 \mathrm{~B}$ reveals that when $\mathrm{Cu}^{2+}$ activities increase from 0 to $0.2 \mu \mathrm{M}$, a depolarization process drives the gill potentials from controlled $-84.2 \mathrm{mV}$ to nearly $55 \mathrm{mV}$ and $10 \mathrm{mV}$ at $\mathrm{Na}^{+}$activities of 0.1 and $2.8 \mathrm{mM}$, respectively. On the other hand, $\mathrm{Cu}$ membrane potential changes decrease with increasing of $\mathrm{Cu}^{2+}$ activities (Figure $2 \mathrm{C}$ ).

Figure 2. Predictions of clam gill membrane potentials. (A) $\mathrm{Na}^{+}$activity-dependent $\mathrm{Na}$

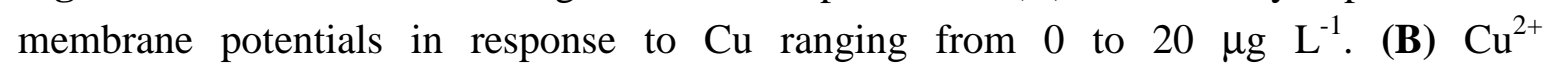
activity-dependent $\mathrm{Na}$ membrane potentials at $\mathrm{Na}^{+}$activity ranging from 0.1 to $2.8 \mathrm{mM}$. (C) $\mathrm{Cu}$ membrane potential changes range from 0 to $-40.4 \mathrm{mV}$ varied with $\mathrm{Cu}^{+}$activity ranging from $0-0.2 \mu \mathrm{M}$.
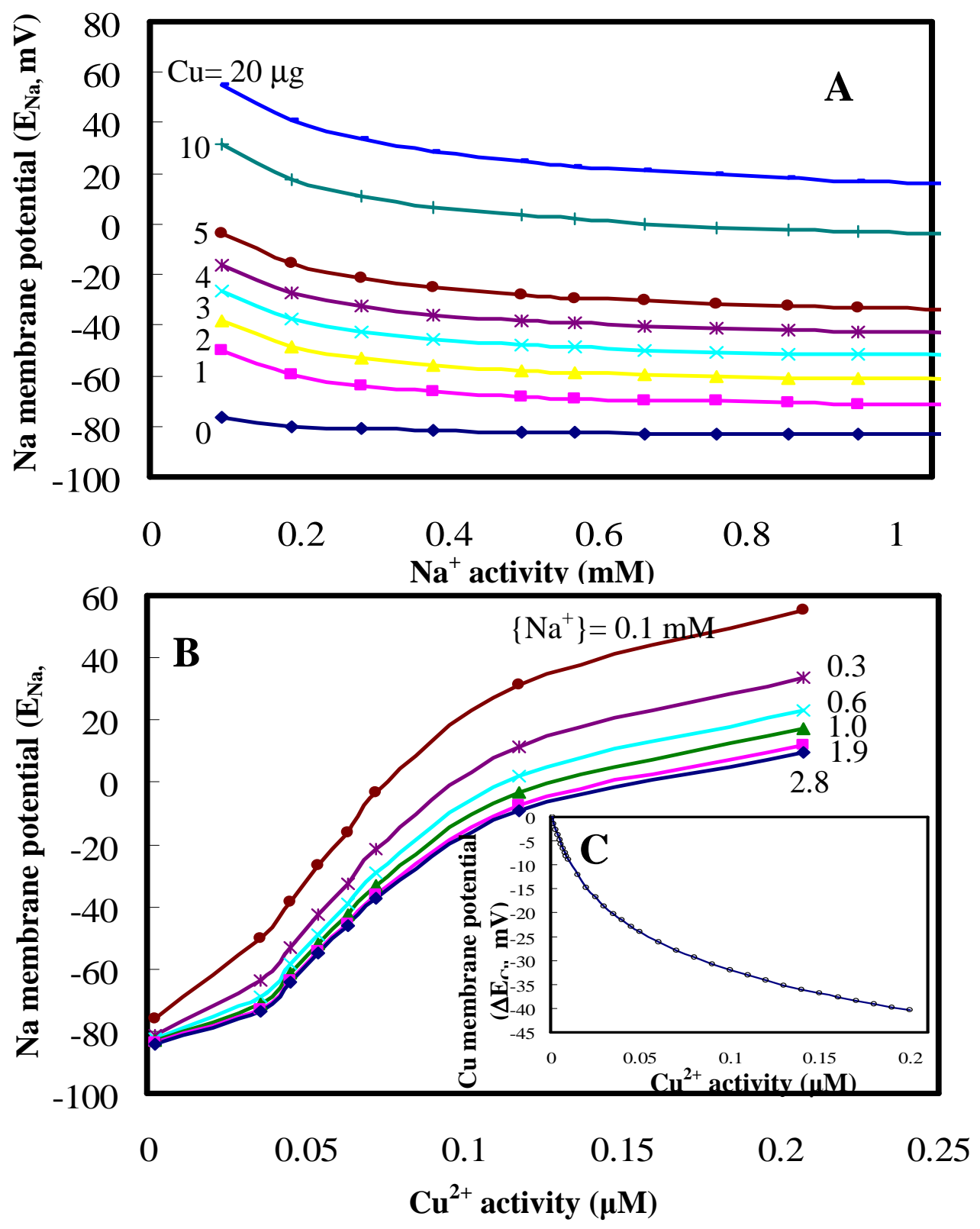
The predicted $\mathrm{Na}^{+}$activity-dependent transport process-specific $\mathrm{Na}$ membrane Nernst potentials decrease sharply when $\mathrm{Na}^{+}$activities are less than $0.1 \mathrm{mM}$ and stay nearly constant when $\mathrm{Na}^{+}$activities are larger than $0.1 \mathrm{mM}$ (Figure 3A). The partitioning ratios of the unidirectional influx of $\mathrm{Na}$ in $C$. fluminea to the total influx are based on the empirical data from [24] (Figure 3B). The predicted $\mathrm{Na}$ uptake rate-Nernst membrane potential profile indicates that $\mathrm{Na}$ membrane potentials decrease from +10 to $-84 \mathrm{mV}$ with increasing $\mathrm{Na}$ uptake rates ranging from $0.1-13 \mu \mathrm{mol} \mathrm{g}^{-1} \mathrm{~h}^{-1}$ (Figure 3C). Decreasing of $\mathrm{Cu}$ uptake rates from $0.35-0.05 \mu \mathrm{mol} \mathrm{g}^{-1} \mathrm{~h}^{-1}$ results in a increasing $\mathrm{Cu}$ membrane potential changes from $-40-0 \mathrm{mV}$ (Figure 3D).

Figure 3. Physiological and electrophysiological kinetics of $\mathrm{Na}$ flux partitions: (A) $\mathrm{Na}$ membrane potentials and (B) the unidirectional $\mathrm{Na}$ influx. Predicted the profiles of ion uptake rate - Nernst membrane potentials for (C) $\mathrm{Na}$ and (D) $\mathrm{Cu}$.
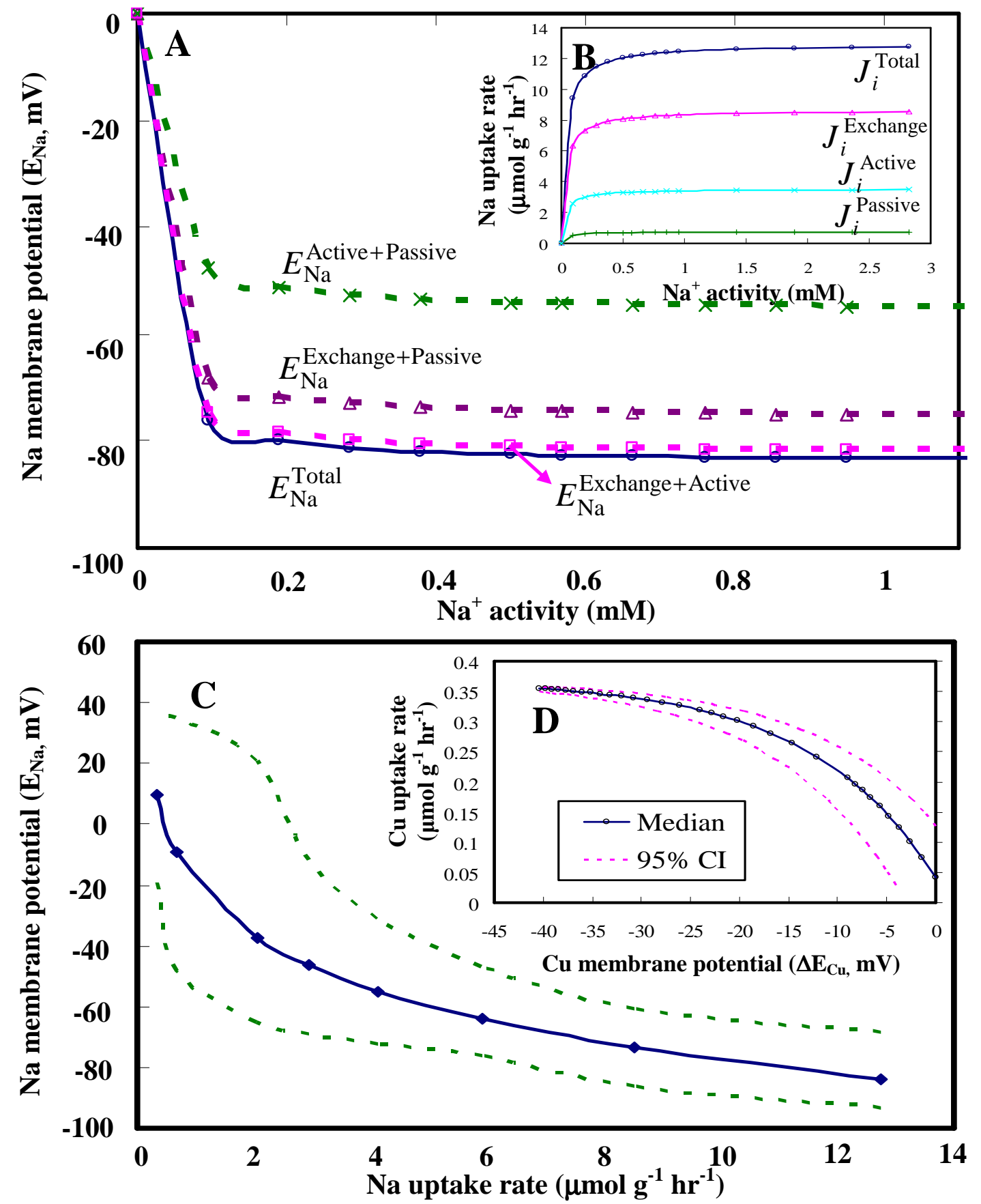
We predicted the relationship between clam valve closure behavior and electrophysiological properties by using the valve closure response-Na membrane potential profile to assess the biological responses (Figure 4A). A sharp change of valve closure responses from 10 to $76 \%$ occurred when $\mathrm{Na}$ membrane potentials increase from -84 to $-74 \mathrm{mV}$. Clams experience a smooth closure response from 76 to $100 \%$ when Na membrane potentials notably increase from -74 to $10 \mathrm{mV}$ (Figure 4A). The 50\% inhibitory $\mathrm{Na}$ membrane potentials (IP50) for valve closure response and $\mathrm{Na}$ uptake rate are, respectively, $-73.54 \mathrm{mV}$ and $-64.16 \mathrm{mV}$ (Figures 4A, B). Figure 4C demonstrates the $\mathrm{Cu}^{2+}$ activity-dependent interplay among valve closure response behavior, gill potentials, and $\mathrm{Na}$ uptake rates, revealing a substantial link between ecotoxicology ( $\mathrm{Cu}$ bioavailability) and electrophysiology ( $\mathrm{Na}$ transport and gill potentials) in C. fluminea. It plays a crucial role in determining the kinetics of gill ligand binding mechanisms.

Figure 4. Predicted biological and electrophysiological responses that includes clam valve closure behavior, Na uptake, and gill potentials. (A) Relationships between closure response and electrophysiological properties ( $\mathrm{Na}$ membrane potential). (B) Relationships between inhibition of $\mathrm{Na}$ uptake and $\mathrm{Na}$ membrane potential. (C) $\mathrm{Cu}^{2+}$ activity-dependent interactions, showing that changes of valve closure response, $\mathrm{Na}$ uptake rate, and $\mathrm{Na}$ membrane potential.
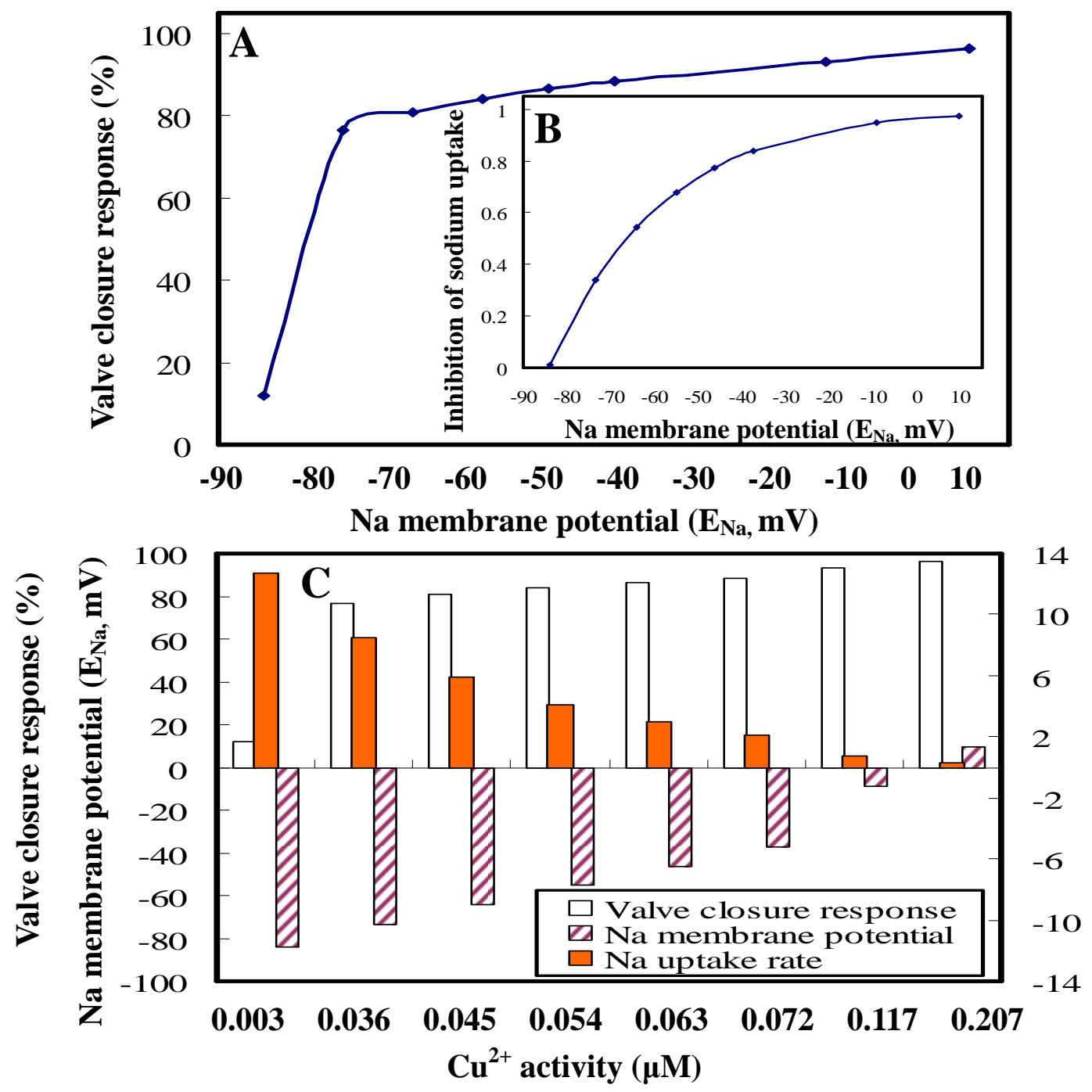


\subsection{Model applications}

We reconstructed Hill-based dose-response relationships between inhibitions of $\mathrm{Na}$ membrane potential and $\mathrm{Na}$ uptake rate and $\mathrm{Cu}^{2+}$ activities. The results indicate that $50 \%$ inhibitory concentrations (IC50) for Na membrane potential and uptake rate are best estimated $\left(r^{2}=0.99\right)$ to be 0.072 and 0.043 $\mu \mathrm{M} \mathrm{Cu}^{2+}$ with fitted Hill coefficients of 2.95 and 3.29, respectively (Figure 5A). The $\mathrm{Cu}^{2+}$ activity-dependent $\mathrm{Na}$ uptake rate profiles partitioning with different transport mechanisms are shown in Figure 5B. To assess the effect of external $\mathrm{Cu}^{2+}$ activity on gill potential at nonequilibrium conditions, we estimated the $\mathrm{Cu}^{2+}$ activity-dependence gill active potentials based on the $\mathrm{Cu}^{2+}$ activity-dependence Na uptake rate profiles (Figure 5B).

At a nonequilibrium condition, the predicted active gill potentials have a mild depolarization process from -8.2 to $0 \mathrm{mV}$ when external $\mathrm{Cu}^{2+}$ activities increase from $0-0.2 \mu \mathrm{M}$ (Figure 5C). The result demonstrates that a sigmoidal dependence on the external $\mathrm{Cu}^{2+}$ activities followed a best fitted Hill equation $\left.E_{\mathrm{Na}}^{\text {Active }}=-8.2+\left(\left(E_{\max } \times\left\{\mathrm{Cu}^{2+}\right\}^{n}\right) /\left(\mathrm{EC}_{\text {active }} 50\right)^{n}+\left\{\mathrm{Cu}^{2+}\right\}^{n}\right)\right)$ with a Hill coefficient $n=2.97$, $E_{\max }=8.2$, and the effective $\mathrm{Cu}$ activity that block $50 \%$ of active $\mathrm{Na}^{+}$channel transport $\left(\mathrm{EC}_{\text {active }} 50\right)$ is estimated to be $0.072 \mu \mathrm{M}\left(r^{2}=0.99\right)$.

This result implies that three $\mathrm{Cu}^{2+}$ ions bind to a single site in the outer gill membrane pore of the $\mathrm{Na}^{+}$ channel to block the active Na transport. It results in a depolarization-induced shift of clam behaviors such as daily valve closing/opening rhythm and siphoning capacity from high to low in response to waterborne $\mathrm{Cu}$. We therefore incorporated the fitted $E_{\mathrm{Na}}^{\text {Active }}$ function into Eq. (18) to estimate internal $\mathrm{Na}$ concentration in $C$. fluminea. A parsimonious exponential function $\left(\left[\mathrm{Na}^{+}\right]_{\mathrm{i}}=6.37+4.27 \times \exp \right.$ $\left.\left(\left\{\mathrm{Cu}^{2+}\right\} / 0.147\right), r^{2}=0.96\right)$ best describes the relationship between the external $\mathrm{Cu}^{2+}$ activity and internal Na concentration in blood (Figure 5D).

We employed our proposed framework to predict site-specific clam valve closure behavior (Eq. (T1)), Na uptake rate (Eq. (T7)), and associated gill membrane potentials in response to waterborne $\mathrm{Cu}$ (Eq. (7)) for major clam farms located at Changhua and Hualien, respectively, in the southwestern and eastern Taiwan. The adopted water quality data for Changhua and Hualien farms are listed in Table 2. Figure 6 reveals that physiological and electrophysiological characteristics of $C$. fluminea in Changhua clam farm are more sensitive than those in Hualien. This result suggests that the proposed bio-electrophysiological model could be used to test the bivalve biological and electrophysiological response abilities to close its shell as an alarm signal to reflect clam's health when exposed to waterborne metals by taking account of the metal bioavailability. Figure $6 \mathrm{C}$ also shows that the site-specific clam gill potentials could be predicted by the present model and could also be used in the assessment of metal ion bioavailability in the aquaculture settings.

\subsection{Clam gill potential as a determinant in environmental risk assessment}

We proposed the mechanistic models based on concepts obtained from BLM, M-M kinetics, and electrochemistry to explore the interplay among valve closure behavior, $\mathrm{Na} / \mathrm{Cu}$ transport, and gill membrane potentials. 
Figure 5. Predicted dose-response profiles. (A) Hill-based dose-response profiles showing the relationships between inhibitions of $\mathrm{Na}$ membrane potential/Na uptake rate and $\mathrm{Cu}^{2+}$ activity. (B) $\mathrm{Cu}^{2+}$ activity-dependent $\mathrm{Na}$ uptake rate profiles partitioning with different transport mechanisms of exchange, passive, active, and total influxes. (C) Prediction of active gill potentials at a non-equilibrium condition, showing increasing of $\mathrm{Cu}^{2+}$ activities has a mild depolarization process from -8.2 to $0 \mathrm{mV}$. (D) Predicted $\mathrm{Cu}^{2+}$ activity-dependent internal $\mathrm{Na}$ concentration in blood showing the changes of internal $\mathrm{Na}$ concentration from 10.56 to $7.40 \mathrm{mM}$ varied with $\mathrm{Cu}^{+}$activities ranging from $0-0.21 \mu \mathrm{M}$.
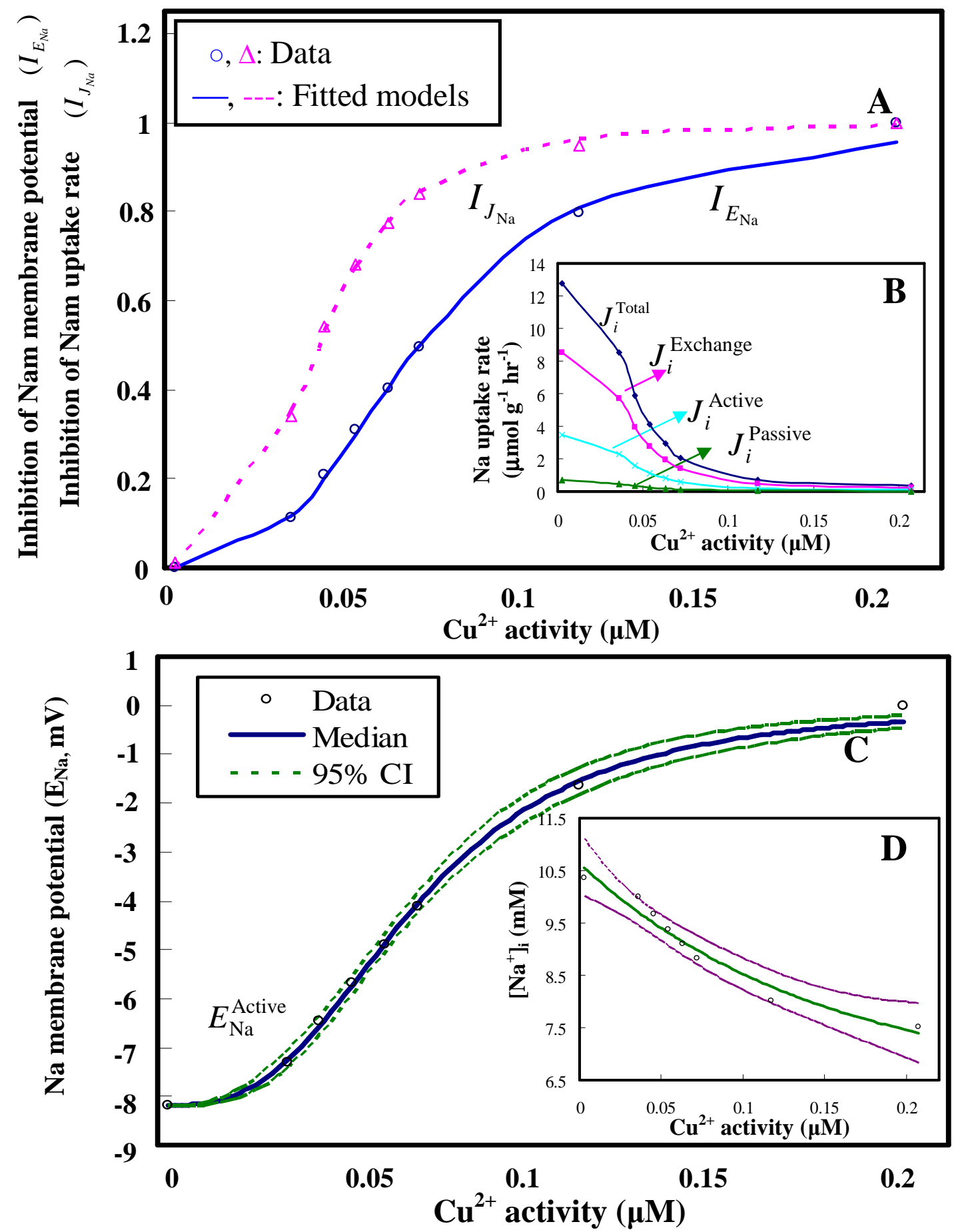
Table 2 Measured $\mathrm{pH}$ and temperature values with the ion activities of key water chemistry characteristics calculated by WHAM from published data for two selected clam farms of Changhua and Hualien

\begin{tabular}{cccccccc}
\hline & & & \multicolumn{5}{c}{ Ion activities (mM) } \\
& $\mathrm{pH}$ & Temp. $\left({ }^{\circ} \mathrm{C}\right)$ & $\mathrm{Ca}^{2+}$ & $\mathrm{Mg}^{2+}$ & $\mathrm{Na}^{+}$ & $\mathrm{Cl}^{-}$ & $\mathrm{SO}_{4}^{2-}$ \\
\hline Changhua $^{\text {a }}$ & $8.01 \pm 0.19$ & $29.3 \pm 0.9$ & $0.41 \pm 0.14$ & $0.34 \pm 0.08$ & $0.43 \pm 0.23$ & $0.40 \pm 0.25$ & $0.098 \pm 0.15$ \\
Hualien $^{\text {a }}$ & 7.80 & 30.5 & 0.36 & 1.17 & 12.28 & 55.57 & 1.42 \\
\hline
\end{tabular}

\footnotetext{
${ }^{\mathrm{a}}$ Adopted from Liao et al. [31] where data are represented as mean $\pm \mathrm{SD}(n=3)$.
}

Figure 6. Simulations of freshwater clam C. fluminea physiological and electrophysiological characteristics in response to waterborne $\mathrm{Cu}$ for major clam farms located at Changhua and Hualien, showing the site-specific toxicity effect of (A) valve closure response, (B) $\mathrm{Na}$ uptake rates, and (C) $\mathrm{Na}$ membrane potentials varied with $\mathrm{Cu}$ concentrations ranging from $0-150 \mu \mathrm{g} \mathrm{L}^{-1}$.
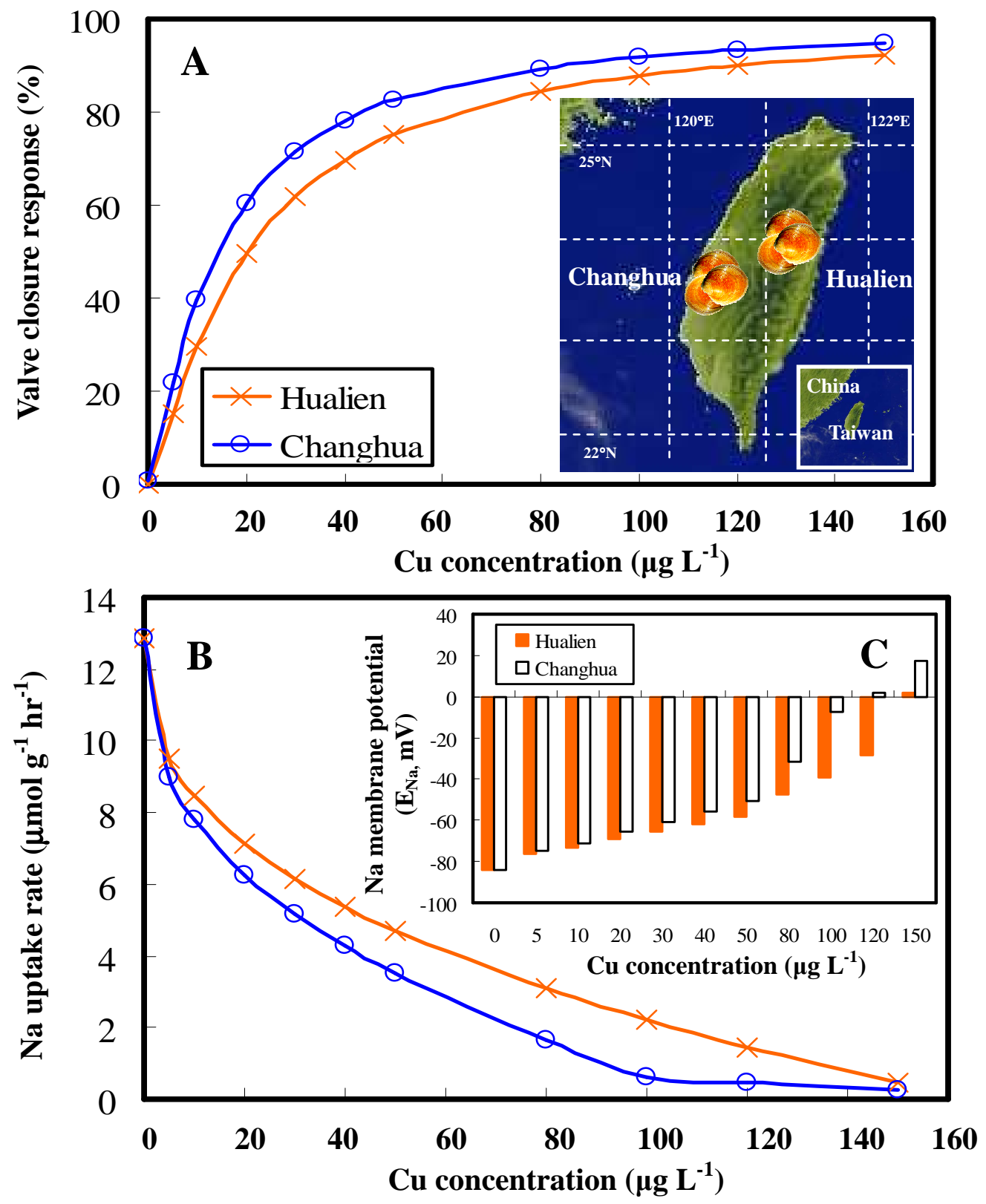
The present model can be used to describe the electrophysiological response in C. fluminea in response to waterborne $\mathrm{Cu}$. A Corbicula-based electrophysiological response framework is developed by incorporating previous Cu-BLM-Corbicula model and flux-biological response kinetics into an electrochemical mechanism for providing an accurately measuring endpoint based on a clam-gill membrane interface. We estimated acute $\mathrm{Cu}$ toxicity that is associated with inhibition of $\mathrm{Na}^{+}$uptake rate involving active $\mathrm{Na}^{+}$membrane potential at the gill interface.

Electrophysiological-based biological responses have been widely applied to variety of species for investigating internal physiological mechanism-based toxicity effects $[21,25,32,33]$ suggested that $\mathrm{Na}^{+}$transmembrane potential difference in mussels was a reasonably good indicator of toxicity. Furthermore, our approach should have a potential to estimate gill damage and individual death by inhibition of $\mathrm{Na}^{+} / \mathrm{K}^{+}-\mathrm{ATPase}$ activity-induce electrophysiological potentials [32].

The estimated dose-response profiles in Figure 5 are the pivotal results for environmental risk assessment in this paper. From our analysis, we predicted the effective $\mathrm{Cu}$ activity that blocks $50 \%$ of active $\mathrm{Na}^{+}$channel transport $\left(\mathrm{EC}_{\text {Active }} 50\right)$ is $0.072 \mu \mathrm{M}$ with a stoichiometry of $3 \mathrm{Cu}^{2+}: 1 E_{\mathrm{Na}}^{\text {Active }}$. That causes a depolarization of the gill membrane by external $\mathrm{Cu}$ ion activity to result in a significant decrease in active $\mathrm{Na}$ influx that directly/indirectly disturbs the clam valve daily opening/closing rhythm. Our results also implicate that the uptake and toxicity of $\mathrm{Cu}$ is much better correlated with activity at gill membrane surface than with activity in the bulk phase medium.

Kinraide [33] argued that the BLM incorporated with free ion activity model (FIAM) generally do not take into account the membrane potentials, although the BLM might consider the gill surface. Consequently, it is often inadequate for the expression of ionic effects, suggesting that membrane potential concept could be used as a general index in assessment of the bioavailability of ions. Kinraide [33] further pointed out that the BLM involves competition among ions as the mechanism of interaction. Site-specific competition, however, cannot explain some instances of interaction. Diffuse electrostatic effects appear to account for the interactions entirely because ions of opposite charge are unlikely to compete for ligand binding sites.

Here we suggested that although site-specific competition among ions might occur, competition only cannot be assessed without consideration of membrane potentials. Therefore we recommended that the effects of membrane potential on the gill-biotic ligand could be incorporated with the effects of binding site competition to assess the metal toxicity. Thus the bioavailability of a metal ion in solution might be dominated more by the membrane potential-depolarizing processes of ions than by competitive interactions of the ions at a ligand binding site.

Cereijido et al. [34] pointed out that epithelia unambiguously demonstrated active Na transport that was first observed by Ussing and Zerahn [35], showing that frog skin can actually transport a net amount of $\mathrm{Na}^{+}$in the inward direction and in the absence of an external electrochemical potential gradient. Assessments of metal risk have been specific for environment and organism. In these cases, our framework that relates the biotic response to $\mathrm{Na}$ active transport-induced active membrane potentials might be adequate. Gill membrane depolarization processes do occur in aquatic animals in response to external stressors [36, 37]. 
Membrane surface activities associated with site-specific binding and competition should be incorporated into the BLM as proxies to represent the bulk phase concentrations where the gill membrane surface activities must be computed from active Na potentials [22, 23, 25, 38, 39]. Bricelj et al. [37] integrated behavioral, electrophysiological, and molecular biological approaches to study the $\mathrm{Na}$ channel mutation that leading to saxitoxin resistance in clams. They indicated that the increased accumulation of toxin in resistance clams points to this resistance mutation as an important risk factor for human paralytic shellfish poisoning (PSP) resulting from the consumption of this species.

Hence our proposed framework linking $\mathrm{Cu}$ bioavailability and electrophysiological responses of $C$. fluminea could provide a practical environmental risk assessment tool. We further suggests that clam gill membrane potential could be adapted as an electrophysiological endpoint of bioavailability and metal toxicity action used in environmental risk analysis to enhance broad risk management strategies [37, 40].

Merging the concepts of ion bioavailability and internalization flux, such as BLM, and M-M kinetics, with the gill membrane potentials described by Nernst and Ussing flux ration equations may provoke new measurement and modeling approaches for monitoring the behavioral dynamics of freshwater bivalves. A new way forward would be a further effort to distinguish between inherent kinetic properties of individual clams and the suite of environmental constraints to response that frequently exists in situ. Although further experiments to investigate the details of multiple transports in biological membranes are underway, the results described here demonstrate that the integration of $\mathrm{Cu}$ bioavailability and electrophysiological responses of $C$. fluminea provided a means to reconfigure mechanisms of active transport across epithelia in bivalves.

The model can be readily extended to account for additional phenomena, such as ATPase activity and $\mathrm{NaCl}$ uptake in the gills of freshwater bivalves. The Nernst equation presented in this paper might be linked with Goldman-Hodgkin-Katz equation, $V_{\mathrm{r}}=R T / F \ln \left\{\left(P_{\mathrm{Na}} / P_{\mathrm{Cl}}\left[\mathrm{Na}^{+}\right]_{\mathrm{o}}+\left[\mathrm{Cl}^{-}\right]_{\mathrm{i}} / P_{\mathrm{Na}} / P_{\mathrm{Cl}}\left[\mathrm{Na}^{+}\right]_{\mathrm{i}}+\right.\right.$

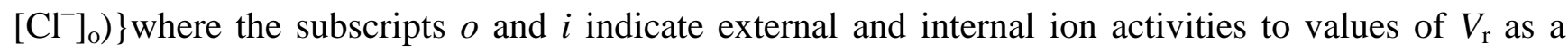
function of $\mathrm{Na}^{+}$and $\mathrm{Cl}^{-}$activities, to calculate resting membrane potential $\left(V_{\mathrm{r}}\right)$ and to estimate the permeability ratio of $P_{\mathrm{Na}} / P_{\mathrm{Cl}}$ while $\mathrm{Cl}^{-}$ion transport in $C$. fluminea is considered. The model has the additional feature that it can be used to address one of the key challenges in biological membrane kinetics, namely, how to determine the active gill potentials of a living clam that responds to external $\mathrm{Cu}$ concentrations. Because the model captures the reorganization of biological and electrophysiological characteristics of clam in response to external free metal ion activities, it can be used as a framework to design and interpret appropriate experiments.

\subsection{Implications for biomonitoring systems}

Our results may have practical implications for future technological and biomonitoring applications. These results provide a scientific basis for future designing the environmental biomonitoring systems. $\mathrm{Cu}$ bioavailability, physiological mechanism of $\mathrm{Na}$ transport, and electrochemical transmembrane that has an important theoretical advantage over traditional toxicity models $[41,42]$ to potentially take into account of both clam physiological and environmental factors affecting metal-induced biological responses. Practically, we have to first observe the valve daily rhythm dynamic fashion in response to $\mathrm{Cu}$ to indirectly obtain a BLM-based concentration-time-response profile. In the following step, we need to 
estimate the waterborne free $\mathrm{Cu}^{2+}$-activity $\left\{\mathrm{Cu}^{2+}\right\}$ by using the major physiological parameters in $C$. fluminea and thus that a real waterborne $\mathrm{Cu}$ ion concentration $\left[\mathrm{Cu}^{2+}\right]$ can then be evaluated depending on the site-specific water quality conditions. We focus on calcium, magnesium, and sodium because they have positive effects against copper toxicity based on BLM scheme [43]. The possible toxicity of copper hydroxide complexes would imply that at the higher $\mathrm{pH}$, less would be needed to exert the same toxic effect. The temperature also has significant effects on the biological behavior or chemical speciation of a toxicant as well. In the future work, such a biomonitoring tool will be implemented to detect toxic effects of multiple metals.

Our proposed model can be applied to develop an artificial clam gill-based membrane interface that mimics ion transports of $\mathrm{Na}$ and $\mathrm{Cu}$ in $C$. fluminea to evaluate the relationships between gill potentials and $\mathrm{Na}$ and $\mathrm{Cu}$ internalization fluxes. The $\mathrm{Na}^{+} / \mathrm{K}^{+}$-ATPase activity and $\mathrm{NaCl}$ uptake in the gills of freshwater bivalves might be further monitored. We anticipate that our model can provide the fundamental properties and methodology to portend broad development of commercial and research applications based on the low cost and procedural and conceptual simplicity of these methods.

The proposed gill-based artificial membrane interface can link with measured bivalve data to quantitatively assess the effects of environmental factors on the biouptake kinetics, ion bioavailability, and electrophysiological performance of membrane devices and the variability of bivalve biodynamics and metabolic availability [10, 44-46]. Successful implementation of in situ biomonitoring is contingent upon understanding how bioavailability of metals, biological, and electrophysiological factors affect the artificial membrane interface kinetically and dynamically [12, 13, 47, 48]. Additional research concerning the gill architecture and geometry of transfer regions [31, 49-50] and dynamics in electrophysiological performances in clams is still necessary to improve the model.

\section{Materials and Methods}

\subsection{Integration model}

The biologically based kinetic reaction of a metal-ligand process in a membrane interface can be described by the Nernst equation as:

$$
\Delta E=\Delta E^{0}-\frac{R T}{n F} \ln \left(\frac{\{M L\}}{[M]\{L\}}\right)
$$

where $\Delta E$ and $n$ are the measured redox potential (V) as an electromotive force (e.m.f.) and the number of electrons transferred, respectively, $\Delta E^{0}$ is the standard state potential, $R$ is the gas constant $(8.3 \mathrm{~J}$ $\left.\mathrm{mol}^{-1} \mathrm{~K}^{-1}\right) ; T$ is absolute temperature $\left({ }^{\circ} \mathrm{K}\right) ;[]$ and \{\} denote the bulk concentration $\left(\mu \mathrm{g} \mathrm{L}^{-1}\right)$ and free ion concentration of a sensitive site on surface in the organism (mole $\mathrm{L}^{-1}$ ), respectively; $M$ and $L$ are the metal concentration and ligand in solution, respectively (mole $\mathrm{L}^{-1}$ ). $\{L\}$ in Eq. (1) can be seen as the site of toxic action in the BLM scheme as: 


$$
[M]+\{L\} \stackrel{K_{S}}{\longrightarrow}\{M L\} \stackrel{k_{\text {int }}}{\longrightarrow}\left\{M_{\text {int }}\right\}+\{L\}
$$

where $k_{\text {int }}$ is internalization rate constant $\left(\mathrm{hr}^{-1}\right)$ and $\left\{M_{\text {int }}\right\}$ represents the metal has been internalized with membrane carrier ligands (mole $\mathrm{g}^{-1}$ ).

Generally, the metal transfer across a biological membrane is assumed to be a first-order process. The internalization flux $(J)$ can be directly related to any metal species in equilibrium, including gill metal burden $\{M L\}$ as:

$$
J=k_{\text {int }} \cdot\{M L\}
$$

We obtained the electrochemistry-based mechanistic model to capture the relationships between internalization flux (uptake) and electrons transferred potential by linking Eqs. (1) and (3),

$$
\Delta E=\Delta E^{0}-\frac{R T}{n F} \ln \left(\frac{k_{\text {int }} \cdot\{M L\}}{k_{\text {int }} \cdot[M] \cdot\{L\}}\right)=\Delta E^{0}-\frac{R T}{n F} \ln \left(\frac{J}{k_{\text {int }} \cdot[M] \cdot\{L\}}\right)
$$

Acute metal toxicity is always associated with inhibition of sites involved in active uptake at gills, resulting in death from failure to maintain homeostasis. We employed the physiological-based mechanistic approach associated with acute metal toxicity to identify species sensitive to metal exposure and further to predict toxic response of biological behavior in C. fluminea.

\subsection{Clam gill-based electrophysiological response model}

The importance of metal bioavailability in metal-ligand chemical reactions is best described by Michaelis-Menten (M-M) kinetics. The internalization flux is $J_{\max } \times[S] /\left(K_{\mathrm{m}}+[S]\right)$ where $[S]$ is metal activity concentration, $J_{\max }$ is the maximum internalization flux, and $K_{\mathrm{m}}$ is the M-M affinity constant, representing the metal activity concentration at which the internalization flux equals $J_{\max } / 2$. When $[S]$ is abundant, $K_{\mathrm{m}}$ becomes insignificant; however, when $[S]$ is low, $K_{\mathrm{m}}$ becomes relevant. We have developed a model (called $\mathrm{Cu}-\mathrm{BLM}$-Corbicula model) [31] to link acute $\mathrm{Cu}$ toxicity and its effect on valve closure behavior in freshwater clam $C$. fluminea to support the biotic ligand model (BLM). That model confirms that BLM could be improved to analytically and rigorously describe the bioavailable fraction of metal causing toxicity to valve closure behavior in freshwater $C$. fluminea. We have also provided a flux transport model based on BLM and M-M kinetics to link valve closure behavior and $\mathrm{Na}^{+}$ transport mechanism in C. fluminea [52] (Figure 1B).

Table 3 lists the essential mathematical equations used to describe the Cu-BLM-Corbicula model and the flux-biological response framework. Table 3 embraces $\mathrm{Na}$ transport-valve closure response model, $\mathrm{Na}$ transport, and $\mathrm{Cu}$ internalization flux kinetics.

Here we integrated flux-biological response mechanisms and Cu-BLM-Corbicula model (Eqs. (T1) (T3)), taking into account the bioavailability and physiological response, into thermodynamics-based Nernst equation to formulate a clam gill-based electrophysiological response model. We firstly linked electrochemistry-based mechanistic model (Eq. (T4)) and Na transport-valve closure response model 
(Eqs. (T4) - (T6)) to obtain the key relationships among valve closure response, Na uptake rate, and gill Na membrane potentials:

$$
\begin{aligned}
E_{\mathrm{Na}^{+}} & =\frac{R T}{n F} \ln \left(\frac{J_{\mathrm{Na}^{+}}(\phi)}{k_{\mathrm{int}} \cdot\left[\mathrm{BL}^{-}\right] \cdot\left\{\mathrm{Na}^{+}\right\}}\right) \\
& =\frac{R T}{1 \cdot F} \ln \left(\frac{J_{\text {max }} \times\left[1-\frac{1 \times \phi^{m(\Delta t)}}{\left[\mathrm{ER} 50_{\phi}(\Delta t)\right]^{m(\Delta t)}+\phi^{m(\Delta t)}}\right]}{k_{\mathrm{int}} \cdot\left[\mathrm{BL}^{-}\right] \cdot\left\{\mathrm{Na}^{+}\right\}}\right),
\end{aligned}
$$

where $E_{\mathrm{Na}^{+}}$represents the gill $\mathrm{Na}$ membrane potential $(\mathrm{mV}), \phi$ is a $\left\{\mathrm{Cu}^{2+}\right\}$-dependent clam valve closure response function taking into account external $\mathrm{Na}^{+}$activity based on Cu-BLM-Corbicula model (Eqs. (T1) - (T3)), $m(\Delta t)$ is the response time-dependent Hill coefficient, ER50 $(\Delta t)$ is the $50 \%$ effective response due to the $\%$ inhibition of $\mathrm{Na}^{+}$uptake rate, and $\left[\mathrm{BL}^{-}\right]$is the concentration of unoccupated gill BL sites $\left(\mu \mathrm{mol} \mathrm{g} \mathrm{g}^{-1}\right)$.

We refined Eq. (5) for further predicting the variable membrane potential based on different ion species transporting across gill membrane in C. fluminea. We incorporated Na transport kinetics (Eqs. (T7) - (T9)) into Eq. (5) to describe the performance of Na membrane potentials:

$$
E_{\mathrm{Na}^{+}}=\frac{R T}{1 \cdot F} \ln \left(\frac{\frac{J_{\mathrm{Na}^{+}, \max }\left(\left\{\mathrm{Cu}^{2+}\right\}\right) \times\left\{\mathrm{Na}^{+}\right\}}{K_{m, \mathrm{Na}^{+}}\left(\Delta t,\left\{\mathrm{Cu}^{2+}\right\}\right)+\left\{\mathrm{Na}^{+}\right\}}}{k_{\mathrm{int}} \cdot\left[\mathrm{BL}^{-}\right] \cdot\left\{\mathrm{Na}^{+}\right\}}\right)
$$

On the other hand, $\mathrm{Cu}$ membrane potential $\left(E_{\mathrm{Cu}^{2+}}\right)$ can be described by the $\mathrm{Cu}$ internalization flux kinetics (Eq. (T10)) as:

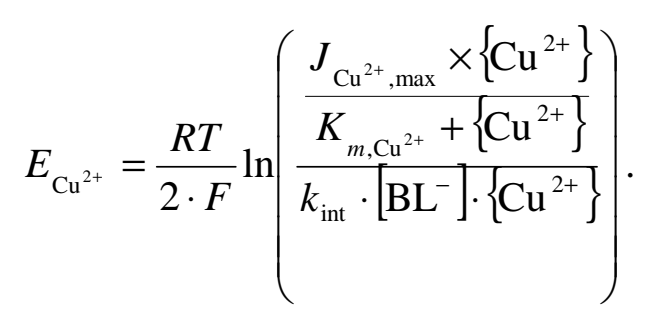

Eqs. (6) and (7) provide the information of an accurately electrophysiological response-based mechanisms to estimate the gill membrane potentials for further estimating the waterborne $\mathrm{Cu}$ toxicity. 
Table 3 The mathematical descriptions for $\mathrm{Cu}$-BLM-Corbicula model associated with $\mathrm{Na}$ transport mechanism and valve closure response in $C$. fluminea in response to waterborne $\mathrm{Cu}$ (see text for the meanings of symbols)

Cu-BLM-Corbicula model ${ }^{\mathrm{a}}$

$\phi\left(\Delta t, \mathrm{Cu}^{2+}\right)=\frac{\phi_{\max } \times\left\{\mathrm{Cu}^{2+}\right\}^{n(\Delta t)}}{\left[\mathrm{EC} 50(\Delta t)_{\mathrm{CuBL}}\right]^{n(\Delta t)}+\left\{\mathrm{Cu}^{2+}\right\}^{n(\Delta t)}}$

Time-varying Hill coefficient function in valve closure response

$n(\Delta t)=1.221+0.988 \exp (-\Delta t / 37.7), r^{2}=0.89$

Time-varying BLM-predicted 50\% effective response concentration function

$\operatorname{EC} 50(\Delta t)_{\mathrm{CuBL}}=\frac{f_{\mathrm{CuBL}}^{50 \%}(\Delta t)}{\left(1-f_{\mathrm{CuBL}}^{50 \%}(\Delta t)\right)}\left(\frac{1+K_{\mathrm{CaBL}}\left\{\mathrm{Ca}^{2+}\right\}+K_{\mathrm{MgBL}}\left\{\mathrm{Mg}^{2+}\right\}+K_{\mathrm{NaBL}}\left\{\mathrm{Na}^{+}\right\}+K_{\mathrm{HBL}}\left\{\mathrm{H}^{+}\right\}}{K_{\mathrm{CuBL}}+K_{\mathrm{CuOHBL}} K_{\mathrm{CuOH}}\left\{\mathrm{OH}^{-}\right\}+K_{\mathrm{CuCO}_{3} \mathrm{BL}} K_{\mathrm{CuCO}_{3}}\left\{\mathrm{CO}_{3}^{2-}\right\}}\right)$

Sodium transport - valve closure response model ${ }^{\mathrm{b}}$

$$
\begin{aligned}
J_{\mathrm{Na}^{+}}(\phi) & \equiv J_{\mathrm{Na}^{+}}\left(\Delta t, \phi\left(\Delta t, \mathrm{Cu}^{2+}, \mathrm{Na}^{+}\right)\right)=J_{\max } \times\left(1-I_{J_{\mathrm{Na}^{+}}}\left(\Delta t, \phi\left(\Delta t, \mathrm{Cu}^{2+}, \mathrm{Na}^{+}\right)\right)\right) \\
= & J_{\max } \times\left[1-\frac{1 \times \phi^{m(\Delta t)}}{\left[\mathrm{ER} 50,_{\phi}(\Delta t)\right]^{m((\Delta t)}+\phi^{m(\Delta t)}}\right]
\end{aligned}
$$

Time-varying Hill coefficient function in inhibition of $\mathrm{Na}^{+}$uptake

$m(\Delta t)=24.33-778.43 / \Delta t, r^{2}=0.97$

Time-varying $50 \%$ effective response function in inhibition of $\mathrm{Na}^{+}$uptake

$\mathrm{ER} 50_{\phi}(\Delta t)=84.15-1103.27 / \Delta t, r^{2}=0.95$

Sodium transport kinetics ${ }^{b}$

$J_{\mathrm{Na}^{+}}\left(\Delta t, \mathrm{Cu}^{2+}, \mathrm{Na}^{+}\right)=\frac{J_{\max }\left(\left\{\mathrm{Cu}^{2+}\right\}\right) \times\left\{\mathrm{Na}^{+}\right\}}{K_{m}\left(\Delta t,\left\{\mathrm{Cu}^{2+}\right\}\right)+\left\{\mathrm{Na}^{+}\right\}}$

$\left\{\mathrm{Cu}^{2+}\right\}$-dependent maximum $\mathrm{Na}^{+}$uptake function

$J_{\max }\left(\left\{\mathrm{Cu}^{2+}\right\}\right)=0.345+12.90 \exp \left(\frac{-\left\{\mathrm{Cu}^{2+}\right\}}{6.154 \times 10^{-8}}\right), r^{2}=0.85$

Response time- and $\left\{\mathrm{Cu}^{2+}\right\}$-dependent half-saturation affinity constant function

$$
\begin{aligned}
& K_{m}\left(\Delta t,\left\{\mathrm{Cu}^{2+}\right\}\right)=a_{1}(\Delta t)\left\{\mathrm{Cu}^{2+}\right\}^{a_{2}(\Delta t)} \\
& a_{1}(\Delta t)=3.84+193.66 \exp (-\Delta t / 136.23), r^{2}=0.99 \\
& a_{2}(\Delta t)=0.862 \exp (-\Delta t / 2875.88), r^{2}=0.68
\end{aligned}
$$

Copper internalization flux kinetics ${ }^{b}$

$$
J_{\mathrm{Cu}^{2+}} \equiv \frac{[C u B L]_{\mathrm{T}}}{\Delta t}=\frac{J_{\mathrm{Cu}^{2+}, \max } \times\left\{\mathrm{Cu}^{2+}\right\}}{K_{m, \mathrm{Cu}^{2+}}+\left\{\mathrm{Cu}^{2+}\right\}}
$$

${ }^{\text {a }}$ Adopted from Liao et al. [31].

${ }^{\mathrm{b}}$ Adopted from Liao et al. [52]. 
By linking Ussing flux ratio equation $[24,53]$ with Eq. (6), the external $\mathrm{Cu}$ concentration-dependent internal (blood) Na concentration in C. fluminea can be estimated to be:

$$
\left[\mathrm{Na}^{+}\right]_{i}=\left(\left[\mathrm{Na}^{+}\right]_{o} \frac{J_{\mathrm{o}}^{\text {Diffusion+Excretion }}}{J_{\mathrm{i}}^{\text {Diffusion }}}\right) \exp \left(\frac{F E_{\mathrm{Na}}^{\text {Active }}}{R T}\right),
$$

where $\left[\mathrm{Na}^{+}\right]_{\mathrm{i}}$ and $\left[\mathrm{Na}^{+}\right]_{\mathrm{o}}$ are the internal (blood) and external Na concentrations $(\mu \mathrm{M})$, respectively, the Ussing flux ratio $\left(J_{\mathrm{o}}^{\text {Diffusion+Excretion }} / J_{\mathrm{i}}^{\text {Diffusion }}\right)$ could be obtained from [24] and was estimated to be 5.74, and $E_{\mathrm{Na}}^{\text {Active }}(\mathrm{mV})$ is the $\mathrm{Na}$ membrane potential due to the active transport mechanism that can be estimated by our present model framework.

\section{Conclusions}

Our analysis of $\mathrm{Cu}$ bioavailability and electrophysiological response interactions in $C$. fluminea leads to several conclusions. We present an ecotoxicologically-electrophysiologically inspired model for the kinetic reconsideration of the clam valve response behavior that incorporates $\mathrm{Na}$ active transport mechanism. It entails a highly nonlinear interaction among external $\mathrm{Cu}$ bioavailability, $\mathrm{Cu}$-gill ligand binding affinity, $\mathrm{Na} / \mathrm{Cu}$ internalization kinetics, and depolarization processes of gill transmembrane potentials. The framework captures the features observed in model applications including ( $i$ ) 50\% inhibitory $\mathrm{Cu}^{2+}$ activities for $\mathrm{Na}$ membrane potential and uptake rate are estimated to be 0.072 and 0.043 $\mu \mathrm{M}$, with a stoichiometry of $3 \mathrm{Cu}^{2+}: 1 E_{\mathrm{Na}}$ and $1 J_{\mathrm{Na}}$, (ii) the external $\mathrm{Cu}^{2+}$-dependent internal $\mathrm{Na}$ concentration can be parsimoniously estimated, and (iii) the site-specific clam gill potentials can be predicted in the aquaculture settings. Our study suggests that a detailed understanding of the nature of ion bioavailability-electrophysiology interactions, together with identification of valve response behaviors validated in an aquaculture setting, can be combined with physiologically-based toxicokinetics and toxicodynamics to identify the sites and mechanisms of action of metabolically available metal and stored detoxified metal in aquaculture species.

\section{References and Notes}

1. Doherty, F.G.; Cherry, D.S.; Cairns, J. Valve closure responses of the Asiatic clam Corbicula fluminea exposed to cadmium and zinc. Hydrobiologia 1987, 153, 159-167.

2. Sluyts, H.; VanHoof, F.; Cornet, A.; Paulussen, J. A dynamic new alarm system for use in biological early warning systems. Environ. Toxicol. Chem. 1996, 15, 1317-1323.

3. Borcherding, J.; Jantz, B. Valve movement response of the mussel Dreissena polymorpha - the influence of $\mathrm{pH}$ and turbidity on the acute toxicity of pentachlorophenol under laboratory and field conditions. Ecotoxicology 1997, 6, 153-165.

4. Curtis, T.M.; Williamson, R.; Depledge, M.H. Simultaneous, long-term monitoring of valve and cardiac activity in the blue mussel Mytilus edulis exposed to copper. Mar. Biol. 2000, 136, 837-846.

5. Weis, J. S.; Samson, J.; Zhou, T.; Skurnick, J.; Weis, P. Prey capture ability of mummichogs (Fundulus heteroclitus) as a behavioral biomarker for contaminants in estuarine systems. Can. J.

Fish. Aquat. Sci. 2001, 58, 1442-1452. 
6. Tran, D.; Ciret, P.; Ciutat, A.; Durrieu, G.; Massabuau, J.C. Estimation of potential and limits of bivalve closure response to detect contaminants: Application to cadmium. Environ. Toxicol. Chem. 2003, 22, 914-920.

7. Tran, D.; Fournier, E.; Durrieu, G.; Massabuau, J.C. Copper detection in the Asiatic clam Corbicula fluminea: optimum valve closure response. Aquat. Toxicol. 2004, 66, 333-343.

8. El-Shenawy, N.S. Heavy-metal and microbial depuration of the clam Ruditapes decussatus and its effect on bivalve behavior and physiology. Environ. Toxicol. 2004, 19, 143-153.

9. Perez, M.H.; Wallace, W.G. Differences in prey capture in grass shrimp, Palaemonetes pugio, collected along an environmental impact gradient. Arch. Environ.l Contam. Toxicol. 2004, 46, 81-89.

10. Booij, K.; Smedes, F.; van Weerlee, E.M.; Honkoop, P.J.C. Environmental monitoring of hydrophobic organic contaminants: The case of mussels versus semipermeable membrane devices. Environ. Sci. Technol. 2006, 40, 3893-3900.

11. van Leeuwen, H.P.; Köster, W. Physicochemical kinetics and transport at biointerface. In Physicochemical Kinetics and Transport at Biointerfaces; van Leeuwen, H. P.; Köster, W.; Wiley: Chichester, 2004; pp. 1-14.

12. van Leeuwen, H.P.; Town, R.M.; Buffle, J.; Cleven, R.; Davison, W.; Puy, J.; van Riemsdijk, W. H.; Sigg, L. Dynamic speciation analysis and bioavailability of metals in aquatic systems. Environ. Sci. Technol. 2005, 39, 8545-8556.

13. Tercier-Waeber, M.L.; Confalonieri, F.; Riccardi, G.; Sina, A.; Noel, S.; Buffle, J.; Graziottin, F. Multi Physical-Chemical profiler for real-time in situ monitoring of trace metal speciation and master variables: Development, validation and field applications. Mar. Chem. 2005, 97, 216-235.

14. Morgan, T.P.; Wood, C.M. A relationship between gill silver accumulation and acute silver toxicity in the freshwater rainbow trout: Support for the acute silver biotic ligand model. Environ. Toxicol. Chem. 2004, 23, 1261-1267.

15. Zhou, B.S.; Nichols, J.; Playle, R.C.; Wood, C.M. An in vitro biotic ligand model (BLM) for silver binding to cultured gill epithelia of freshwater rainbow trout (Oncorhynchus mykiss). Toxicol. Appl. Pharmacol. 2005, 202, 25-37.

16. Hedgepeth, M.E. Salinity related changes in ATPase levels in the Virginia oyster, Crassostrea virginia and the hard clam, Mercenaria mercenaria. Va. J. Sci. 1974, 25, 64. (abstract)

17. Dietz, T.H.; Findley, A.M. Ion-stimulated ATPase activity and $\mathrm{NaCl}$ uptake in the gills of fresh-water mussels. Can. J. Zool. 1980, 58, 917-923.

18. Handy, R.D.; Eddy, F.B. Transport of solutes across biological membranes in eukaryotes. In Physicochemical Kinetics and Transport at Biointerfaces; van Leeuwen, H. P.; Köster, W.; Wiley: Chichester, 2004; pp. 337-356.

19. Reyes, N.; Gadsby, D.C. Ion permeation through the $\mathrm{Na}^{+}, \mathrm{K}^{+}$-ATPase. Nature 2006, 443, 470-474.

20. Wilkinson, K.J.; Buffle, J. Critical evaluation of the physicochemical parameters and processes for modeling the biological uptake of trace metals in environmental (aquatic) system. In Physicochemical Kinetics and Transport at Biointerfaces; van Leeuwen, H. P.; Köster, W.; Wiley: Chichester, 2004; pp. 445-533. 
21. Potts, W.T.W.; Eddy, F.B. Gill potentials and sodium fluxes in flounder Platichthys flesus. J. Comp. Physiol. 1973, 87, 29-48.

22. Ussing, H.H.; Erlij, D.; Lassen, U. Transport pathways in biological membranes. Annu. Rev. Physiol. 1974, 36, 17-49.

23. Fletcher, C.R. Potential dependence of sodium fluxes across gills of marine teleosts. J. Cel. Comp. Physiol. 1977, 117, 277-289

24. McCorkle, S.; Dietz, T.H. Sodium transport in the freshwater Asiatic clam Corbicula fluminea. Biol. Bull. 1980, 159, 325-336.

25. Potts, W.T.W.; Hedges, A.J. Gill potentials in marine teleosts. J. Comp. Physiol. B, Biochem. Syst. Environ. Physiol. 1991, 161, 401-405.

26. Dietz, T.H.; Byrne, R.A. Potassium and rubidium uptake in freshwater bivalves. J. Exp. Biol. 1990, 150, 395-405.

27. Dietz, T.H.; Hagar, A.F. Chloride uptake in isolated gills of the freshwater mussel Ligumia subrostrata. Can. J. Zool. 1990, 68, 6-9.

28. Wilcox, S.J.; Dietz, T.H. Potassium transport in the freshwater bivalve Dreissena polymorpha. J. Exp. Biol. 1995, 198, 861-868.

29. Zheng, H.Y.; Dietz, T.H. Ion transport in the freshwater bivalve Corbicula fluminea. Biol. Bull. 1998, 194, 161-169.

30. Haynie, D.T. Biological Thermodynamics. Cambridge University Press: New York. 2001.

31. Liao, C.M.; Jou, L.J.; Lin, C.M.; Chiang, K.C.; Yeh, C.H.; Chou, B.Y.H. Predicting acute copper toxicity to valve closure behavior in the freshwater clam Corbicula fluminea supports the biotic ligand model. Environ. Toxicol. 2007, 22, 295-307.

32. Børseth, J.F.; Aunaas, T.; Einarson, S.; Nordtug, T.; Olsen, A.J.; Zachariassen, K.E. Pollutant-induced depression of the transmembrane sodium-gradient in muscles of mussels. J. Exp. Biol. 1992, 169, 1-18.

33. Kinraide, T.B. Plasma membrane surface potential $\left(\Psi_{\mathrm{PM}}\right)$ as a determinant of ion bioavailability: A critical analysis of new and published toxicological studies and a simplified method for the computation of plant $\Psi_{\mathrm{PM}}$. Environ.l Toxicol. Chem. 2006, 25, 3188-3198.

34. Cereijido, M.; Shoshani, L.; Contreras, R.G. The polarized distribution of $\mathrm{Na}^{+}, \mathrm{K}^{+}$-ATPase and active transport across epithelia. J. Membr. Biol. 2001, 184, 299-304.

35. Ussing, H.H.; Zerahn, K. Active transport of sodium as the source of electric current in the short-circuited isolated frog skin. Acta Physiol. Scand. 1951, 23, 27-110.

36. Kelly, S.P.; Wood, C.M. Cultured gill epithelia from freshwater tilapia (Oreochromis niloticus): Effect of cortisol and homologous serum supplements from stressed and unstressed fish. J. Membr. Biol. 2002, 190, 29-42.

37. Bricelj, V.M.; Connell, L.; Konoki, K.; MacQuarrie, S.P.; Scheuer, T.; Catterall, W.A.; Trainer, V.L. Sodium channel mutation leading to saxitoxin resistance in clams increases risk of PSP. Nature 2005, 434, 763-767.

38. Kirschner, L.B. The study of $\mathrm{NaCl}$ transport in aquatic animals. Am. Zool. 1970, 10, 365-376.

39. Palmer, L.G. $\mathrm{Na}^{+}$transport and flux ratio through apical $\mathrm{Na}^{+}$channels in toad bladder. Nature 1982, 297, 688-690. 
40. Geffeney, S.L.; Fujimoto, E.; Brodie, E.D.; Ruben, P.C. Evolutionary diversification of TTX-resistant sodium channels in a predator-prey interaction. Nature 2005, 434, 759-763.

41. Luoma, S.N.; Rainbow, P.S. Why is metal bioaccumulation so variable? Biodynamics as a unifying concept. Environ. Sci. Technol. 2005, 39, 1921-1931.

42. Tsai, J.W.; Liao, C.M. A dose-based modeling approach for accumulation and toxicity of arsenic in tilapia Oreochromis mossambicus. Environ. Toxicol. 2006, 21, 8-21.

43. De Schamphelaere K.A.C.; Janssen, C.R. A biotic ligand model predicting acute copper toxicity for Daphnia magna: The effect of calcium, magnesium, sodium, potassium, and $\mathrm{pH}$. Environ. Sci. Technol. 2002, 36, 48-54.

44. Rainbow, P.S.; Poirier, L.; Smith, B.D.; Brix, K.V.; Luoma, S.N. Trophic transfer of trace metals: Subcellular compartmentalization in a polychaete and assimilation by a decapod crustacean. Mar Ecol. Prog. Ser. 2006, 308, 91-100.

45. Jou, L.J.; Liao, C.M. A dynamic artificial clam (Corbicula fluminea) allows parsimony on-line measurement of waterborne metals. Environ. Pollut. 2006, 144, 172-183.

46. Wu, R.S.S.; Lau, T.C.; Fung, W.K; Ko; P. H.; Leung, K. M. Y. An 'artificial mussel' for monitoring heavy metals in marine environments. Environ. Pollut. 2007, 145, 104-110.

47. Bayen, S.; Worms, I.; Parthasarathy, N.; Wilkinson, K.; Buffle, J. Cadmium bioavailability and speciation using the permeation liquid membrane. Anal. Chim. Acta 2006, 575, 267-273.

48. Kwon, J.H.; Katz, L.E.; Liljestrand, H.M. Use of a parallel artificial membrane system to evaluate passive absorption and elimination in small fish. Environ. Toxicol. Chem. 2006, 25, 3083-3092.

49. LaBarbera, M. Principles of fluid transport-system in zoology. Science 1990, 249, 992-1000.

50. Medler, S.; Silverman, H. Muscular alteration of gill geometry in vitro: Implications for bivalve pumping processes. Biol. Bull. 2001, 200, 77-86.

51. Bauer, W.R.; Nadler, W. Molecular transport through channels and pores: Effects of in-channel interactions and blocking. Proc. Natl. Acad. Sci. U.S.A. 2006, 103, 11446-11451.

52. Liao, C.M.; Lin, C.M.; Jou, L.J.; Chiang, K.C. Linking valve closure behavior and sodium transport mechanism in freshwater clam Corbicula fluminea in response to copper. Environ. Pollut. 2007, 147, 656-667.

53. Ussing, H.H. The distinction by means of tracers between active transport and diffusion. Acta Physiol. Scand. 1949, 19, 43-56.

(C) 2008 by the authors; licensee Molecular Diversity Preservation International, Basel, Switzerland. This article is an open-access article distributed under the terms and conditions of the Creative Commons Attribution license (http://creativecommons.org/licenses/by/3.0/). 